\title{
Valproat bør unngås hos gravide
}

\author{
Valproat er et potent antiepileptikum med særlig effekt ved generaliserte epilepsier. Det er også godkjent \\ indikasjon ved bipolar lidelse. De senere år er det kommet solid dokumentasjon på at bruk av valproat \\ i svangerskapet gir økt risiko for medfødte misdannelser, kognitiv svikt og autisme hos barnet.
}

Det gikk ikke mange år etter thalidomidtragedien i 1962 før man fant at også barn eksponert for antiepileptika i svangerskapet hadde økt forekomst av medfødte misdannelser sammenliknet med ikke-eksponerte barn (1). Dessverre har det lenge hersket usikkerhet om hvor utbredt dette problemet egentlig er, særlig fordi mange av studiene på dette feltet har hatt metodiske svakheter grunnet små og selekterte pasientmaterialer. De senere år har imidlertid resultater fra store prospektive svangerskapsregistre gitt oss mer valide data om risikoen for medikamentrelaterte fosterskader. Dette har hjulpet oss til å finne en bedre balanse mellom risikoen for anfallsrelaterte fosterskader på den ene side og skader forårsaket av medikamentbruk på den annen side.

\section{Anfall i svangerskapet}

I det største svangerskapsregisteret, EURAP (European Registry of Antiepileptic Drugs and Pregnancy), der 42 land deltar, inkludert Norge, er formålet å kartlegge den komparative risikoen for større føtale misdannelser som følge av bruk av antiepileptika (nye og gamle) i svangerskapet (2). I 3806 graviditeter var $66,6 \%$ av kvinnene helt anfallsfrie under svangerskapet, $15,2 \%$ hadde generaliserte tonisk-kloniske anfall og $0,6 \%$ hadde status epilepticus $(0,3 \%$ var av konvulsiv type). De resterende $17 \%$ hadde mindre, fokale anfall eller absenser som ikke antas å ha fosterskadelige effekter. Anfallene, inkludert status epilepticus, var ikke knyttet til dødelighet hos mødrene (2). Dette står i kontrast til tidligere rapporter om høy føtal og maternell mortalitet ved status epilepticus under graviditet (3). Trolig skyldes denne diskrepansen en kombinasjon av bedret behandling med årene og seleksjonsskjevhet av publikasjoner i tidligere studier, idet det kan ha blitt en overrapportering av fatale hendelser.

Generaliserte tonisk-kloniske anfall i svangerskapet kan gi føtal laktoacidose og hypoksi, og det er funnet at hyppige anfall av denne typen i første trimester er assosiert med reduserte kognitive ferdigheter hos barna i de første leveårene (4).

\section{Bruk av antiepileptika i svangerskapet}

Blant gravide kvinner med epilepsi har vi de senere år sett økt bruk av lamotrigin og levetiracetam, mens bruken av valproat og karbamazepin er gått noe tilbake (5). Dette er positivt, ettersom lamotrigin og levetiracetam ser ut til ha mindre fosterskadelige effekter enn de eldre legemidlene valproat og karbamazepin (6). Antiepileptika som metaboliseres gjennom glukuronidering eller som utskilles uforandret gjennom nyrene, er særlig utsatt for et fall i serumkonsentrasjonen under en graviditet. Dette gjelder for eksempel lamotrigin, okskarbazepin og levetiracetam. Det er derfor særlig viktig å følge opp kvinner som bruker slike medikamenter, og det er nå vanlig å justere opp dosen dersom serumkonsentrasjonen faller med mer enn $35 \%(7,8)$.

\section{$\emptyset$ kt risiko for medfødte misdannelser}

Registerstudiene har vist en samlet malformasjonsrate hos alle barn født av mødre med epilepsi og som bruker antiepileptika på $4,2-6,1 \%$, mot $2-3 \%$ i den generelle befolkningen (9-12). Den er lavere ved bruk av monoterapi og høyere ved bruk av polyterapi, særlig om valproat er involvert $(10,13)$. Malformasjonsraten øker med økende doser av karbamazepin, lamotrigin, valproat og fenobarbital (10).

Ved bruk av monoterapi er det i alle registrene funnet høyest malformasjonrate hos barn eksponert for valproat in utero (9-11, 13-15). Raten hos disse barna er $4,7-10,7 \%$ (5). Forskjellene beror delvis på ulik avgrensning av begrepet «større medfødte misdannelser» og delvis på hvor lang tid barna har vært fulgt opp etter fødselen. Dersom man fjerner de valproateksponerte barna, skiller malformasjonsraten seg ikke signifikant fra barn født av kvinner i den generelle befolkningen $(10,11)$.

Det har vært mye oppmerksomhet rundt faren for ryggmargsbrokk hos barn eksponert for antiepileptika i svangerskapet. Forekomsten av ryggmargsbrokk var i den største registerstudien $1,1 \%$ hos valproateksponerte barn og 0,4\% hos karbamazepineksponerte barn (10). Det er ikke funnet spesifikke misdannelser knyttet til enkeltpreparater. De foreløpige data vi har på den teratogene risikoen knyttet til de nye antiepileptikaene, viser i noen få rapporter økt forekomst av leppe-gane-spalte hos barn eksponert for topiramat $(16,17)$.

\section{$\emptyset$ kt risiko for kognitive problemer og autisme}

Flere studier har vist at barn eksponert for valproat i svangerskapet skårer dårligere på kognitive tester enn barn eksponert for andre antiepileptika og ueksponerte barn (18-21). Ved testing $i$ seks års alder hadde valproateksponerte barn en gjennomsnittlig IQ som var 8-11 poeng lavere enn barn eksponert for karbamazepin, lamotrigin og fenytoin i svangerskapet (valproat: $97, \mathrm{KI}=$ 94-101, karbamazepin: $105, \mathrm{KI}=102-108$, lamotrigin: $108, \mathrm{KI}=105-110$, fenytoin: $108, \mathrm{KI}=104-112)$ (18). Det er også funnet reduserte kognitive funksjoner innen språk og hukommelse og at risikoen for slik svikt øker med økende valproatdose (22-24).

I tillegg er det nylig kommet studier som viser at valproateksponerte barn har en signifikant økt risiko for å utvikle autismespekterforstyrrelse og barneautisme sammenliknet med barn av kvinner i den generelle befolkningen og barn eksponert for andre antiepileptika $(25,26)$. Kvinner som hadde brukt valproat, men sluttet minst 30 dager før konsepsjonen, hadde imidlertid ikke økt risiko for å få barn med autisme, noe som ytterligere styrker muligheten for en sammenheng mellom autisme og bruk av valproat under graviditet (27).

\section{Konklusjon}

Valproat har lenge vært førstevalget hos personer med generaliserte epilepsiformer (28). Legemidlet blir også brukt på andre indikasjoner enn epilepsi. Med den kunnskap vi har i dag, mener vi at unge kvinner med barneønske bør unngå bruk av valproat. Ved generaliserte epilepsier bør man forsøke alternativer som levetiracetam eller lamotrigin. Hvis valproat gir den beste anfallskontrollen, bør det tilstrebes en lavest mulig dose, og helst brukt som monoterapi.

\section{Karl O. Nakken}

karln@ous-hf.no

Erik Taubøll

Karl O. Nakken (f. 1945) er spesialist i nevrologi med spesialkompetanse innen epilepsi. Han er medisinsk fagsjef ved Avdeling for kompleks epilepsi - SSE ved Oslo universitetssykehus og nasjonal koordinator for EURAP-studien i Norge.

Forfatter har fylt ut ICMJE-skjemaet og oppgir ingen interessekonflikter.

Erik Taubøll (f. 1957) er spesialist i nevrologi med spesialkompetanse innen epilepsi. Han er seksjonsoverlege og professor ved Nevrologisk avdeling, Oslo universitetssykehus, Rikshospitalet og leder avdelingens gruppe for epilepsiforskning.

Forfatter har fylt ut ICMJE-skjemaet og oppgir ingen interessekonflikter. 


\section{Litteratur}

1. Meadow SR. Anticonvulsant drugs and congenital abnormalities. Lancet 1968; 2: 1296.

2. Battino D, Tomson T, Bonizzoni E et al. Seizure control and treatment changes in pregnancy: observations from the EURAP epilepsy pregnancy registry. Epilepsia 2013; 54: 1621-7.

3. Teramo K, Hiilesmaa V. Pregnancy and fetal complications in epileptic pregnancies. I: Janz D, Dam $M$ Bossi L et al, red. Epilepsy, pregnancy, and the child. New York, NY: Raven Press, 1982: 53-9.

4. Cummings $C$, Stewart M, Stevenson M et al. Neurodevelopment of children exposed in utero to lamotrigine, sodium valproate and carbamazepine. Arch Dis Child 2011: 96: 643-7.

5. Meador KJ, Penovich P, Baker GA et al. Antiepileptic drug use in women of childbearing age. Epilepsy Behav 2009: 15: 339-43.

6. Campbell E, Kennedy F, Irwin B et al. Malformation risks of antiepileptic drug monotherapies in pregnancy. J Neurol Neurosurg Psychiatry 2013 84: e2.

7. Pennell PB. Antiepileptic drugs during pregnancy: what is known and which AEDs seem to be safest? Epilepsia 2008; 49 (suppl 9): 43-55.

8. Reisinger TL, Newman M, Loring DW et al. Antiepileptic drug clearance and seizure frequency during pregnancy in women with epilepsy. Epilepsy Behav 2013; 29: 13-8.

9. Morrow J, Russell A, Guthrie E et al. Malformation risks of antiepileptic drugs in pregnancy: a prospective study from the UK Epilepsy and Pregnancy Register. J Neurol Neurosurg Psychiatry 2006; 77: 193-8.

10. Tomson T, Battino D, Bonizzoni E et al. Dosedependent risk of malformations with antiepileptic drugs: an analysis of data from the EURAP epi- lepsy and pregnancy registry. Lancet Neurol 2011; 10: 609-17.

11. Veiby G, Daltveit AK, Schjølberg S et al. Exposure to antiepileptic drugs in utero and child development: a prospective population-based study. Epilepsia 2013; 54: 1462-72.

12. Campbell E, Hunt S, Kinney MO et al. The effect of socioeconomic status on treatment and pregnancy outcomes in women with epilepsy in Scotland. Epilepsy Behav 2013; 28: 354-7.

13. Vajda FJ, Hitchcock AA, Graham J et al. The teratogenic risk of antiepileptic drug polytherapy. Epilepsia 2010; 51: 805-10.

14. Artama M, Auvinen A, Raudaskoski T et al. Antiepileptic drug use of women with epilepsy and congenital malformations in offspring. Neurology 2005; 64: 1874-8.

15. Hernández-Díaz S, Smith CR, Shen A et al. Comparative safety of antiepileptic drugs during pregnancy. Neurology 2012; 78: 1692-9.

16. Green MW, Seeger JD, Peterson C et al. Utilization of topiramate during pregnancy and risk of birth defects. Headache 2012; 52: 1070-84.

17. Margulis AV, Mitchell AA, Gilboa SM et al. Use of topiramate in pregnancy and risk of oral clefts. Am J Obstet Gynecol 2012; 207: e1-7.

18. Adab N, Kini U, Vinten J et al. The longer term outcome of children born to mothers with epilepsy. J Neurol Neurosurg Psychiatry 2004; 75: 1575-83.

19. Meador KJ, Baker GA, Browning N et al. Feta antiepileptic drug exposure and cognitive outcomes at age 6 years (NEAD study): a prospective observational study. Lancet Neurol 2013; 12: 244-52.

20. Eriksson K, Viinikainen K, Mönkkönen A et al. Children exposed to valproate in utero-population based evaluation of risks and confounding factors for long-term neurocognitive development. Epilepsy Res 2005; 65: 189-200.

21. Shallcross R, Bromley RL, Irwin B et al. Child development following in utero exposure: levetiracetam vs sodium valproate. Neurology 2011; 76: 383-9.

22. Meador KJ, Loring DW. Risks of in utero exposure to valproate. JAMA 2013; 309: 1730-1.

23. Nadebaum C, Anderson VA, Vajda F et al. Language skills of school-aged children prenatally exposed to antiepileptic drugs. Neurology 2011; 76: 719-26.

24. Bromley RL, Mawer GE, Briggs M et al. The prevalence of neurodevelopmental disorders in children prenatally exposed to antiepileptic drugs. J Neurol Neurosurg Psychiatry 2013; 84: 637-43.

25. Christensen J, Grønborg TK, Sørensen MJ et al. Prenatal valproate exposure and risk of autism spectrum disorders and childhood autism. JAMA 2013; 309: 1696-703.

26. Schneider T, Przewlocki R. Behavioral alterations in rats prenatally exposed to valproic acid: animal model of autism. Neuropsychopharmacology 2005 30: $80-9$.

27. Meador KJ, Loring DW. Risks of in utero exposure to valproate. JAMA 2013; 309: 1730-1.

28. Marson AG, Al-Kharusi AM, Alwaidh M et al. The SANAD study of effectiveness of valproate, lamotrigine, or topiramate for generalised and unclassifiable epilepsy: an unblinded randomised controlled trial. Lancet 2007; 369: 1016-26.

Mottatt 15.10. 2013 og godkjent 16.12. 2013. Redaktør: Tor Rosness.

Publisert først på nett. 